\title{
SIGNIFIKANSI METODE GUIDE READING TERHADAP MOTIVASI BELAJAR SISWA DALAM TEORI MEMBACA NYARING
}

\section{GUIDE READING METHOD ON STUDENTS' LEARNING MOTIVATION IN READING LOUDLY LESSON}

\author{
N Maryani1a, M Ichsan ${ }^{2}$, dan Khairunnisa ${ }^{2}$ \\ 1 Program Studi Manajemen Pendidikan Islam, Fakultas Keguruan dan Ilmu Pendidikan, \\ Universitas Djuanda Bogor, Jl. Tol Ciawi No. 1 Kotak Pos 35 Ciawi Bogor 16720 \\ 2 Program Studi Pendidikan Guru Sekolah Dasar, Fakultas Keguruan dan Ilmu Pendidikan, \\ Universitas Djuanda Bogor, Jl. Tol Ciawi No. 1 Kotak Pos 35 Ciawi Bogor 16720 \\ a Korespondensi: Novi Maryani, Email: novimaryani52@gmail.com \\ (Diterima: 29-07-2017; Ditelaah: 01-08-2017; Disetujui: 30-09-2017)
}

\begin{abstract}
Guide reading Method is a guided learning method aimed to help students in using learning strategy to read independently. While learning motivation is a strong urge and power to achieve certain goals. This research is aimed to find out whether or not the guide reading method affects students' learning motivation in One Grade of SDN 4 Cisande, Sukabumi. This research used correlation method, while the population in SDN 4 Cisande is 34 students and the total samples is 31 students. Instruments used in this research are process worksheet and questionnaire. The data analysis technique was helped by SPSS 16.0 application for Windows. The result shows that students' learning motivation of SDN 4 Cisande is low. It can be seen in the score of the students which are still below the passing grade. Based on analysis of descriptive data of Students' score, the highest score is 288 and the lowest is 182, while the result of descriptive data analysis of students' learning motivation, the highest score is 85 and the lowest is 70 . In normality test, it is obtained significance data $0.188>0,05$ which means score distributes normally. In linearity test, it is obtained significance score $0.428>0,05$, and score of Fcount $=0.545<$ Ftable $=1.85$ which means the data is linear. In data analysis, regression equation in this research obtained data $Y=71.985+0.022$. And data for determination coefficient is $0.1232=0.015$ or $1.5 \% \mathrm{x}$ variable determines $Y$ variable. Significance test through t test, it is obtained score tcount $=0.665<$ ttable $=0.725$ with $\mathrm{dk} 31$, and significance result $0.511>0,05$. The result of hypothesis is Pcount $<$ Ptable so Ha is rejected and Hois accepted. It means that Guide reading Method does not affect learning motivation of students in one grade SDN 4 Cisande, Sukabumi significantly.
\end{abstract}

Keywords: guide reading method, reading loudl, students' learning motivation.

\section{ABSTRAK}

Penelitian ini memiliki tujuan untuk mengetahui apakah ada ataupun tidak ada signifikansi metode guide reading terhadap motivasi belajar siswa di kelas I SDN 4 Cisande Kabupaten Sukabumi. Penelitian ini menggunakan metode korelasi, dengan sampel sebanyak 31 siswa. Penggunaan instrumennya berupa tes berupa Lembar Kerja Proses (LKP) dan angket. Hasil penelitian dari variabel motivasi belajar siswa di SDN 4 Cisande dikatakan rendah, bisa terlihat dari hasil perolehan evaluasi siswa yang masih dibawah kriteria ketuntasan minimal (KKM). Berdasarkan hasil analisis data deskriptif metode guide reading diperoleh nilai tertinggi 288 dan nilai terendah 182, sedangkan hasil analisis data deskriptif motivasi belajar siswa memiliki nilai tertinggi 85 serta nilai terendah 70 . Adapun nilai $F_{\text {hitung }}=0.545<\mathrm{F}_{\text {tabel }}=1.85$ yang berarti data bersifat linear. Pada analisis data, persamaan regresi dalam penelitian ini 
diperoleh data $Y=71.985+0.022$. Serta koefisien determinasi diperoleh data $0.1232=0.015$ atau $1.5 \%$ variabel $\mathrm{X}$ menentukan variabel Y. Uji signifikansi melalui uji t, diperoleh nilai thitung $=0.665<\mathrm{ttabel}=0.725$ dengan $\mathrm{dk} 31$, dan hasil signifikansi $0.511>0,05$. Hasil uji hipotesis didapat Phitung<Ptabel sehingga Ha tolah dan Ho terima. Penelitian ini menyatakan bahwa tidak ada pengaruh yang signifikan antara metode guide reading terhadap motivasi belajar siswa di kelas I SDN 4 Cisande Kabupaten Sukabumi.

Kata kunci: membaca nyaring, metode guide reading, motivasi belajar.

Maryani N, M Ichsan, dan Khairunnisa. 2017. Signifikansi metode guide reading terhadap motivasi belajar siswa dalam teori membaca nyaring. Didaktika Tauhidi Jurnal Pendidikan Guru Sekolah Dasar 4(2): 126-139.

\section{PENDAHULUAN}

Ilmu pengetahuan serta teknologi yang mengalami sebuah perkembangan sangat berpotensi dalam menciptakan dan menghasilkan masyarakat pembelajar. Sebuah proses kegiatan pembelajaran yang baik dan efektif dapat dilakukan melalui kegiatan membaca. Sebagai kegiatan pembelajaran melalui proses berpikir, membaca mencakup aktivitas pengenalan kosa kata, pemahaman akan bahasa, interpretasi, membaca cermat dan kritis, dan pemahaman dengan kreatif. Pengenalan kata bisa berupa kegiatan membaca kata-kata dengan menggunakan kamus (Rahim 2009).

Membaca adalah sebuah aktivitas atau proses pengetahuan dalam upaya menemukan bermacam-macam informasi yang terdapat dalam tulisan bacaan. Membaca juga dapat dikatakan sebagai kegiatan kompleks dengan menggerakkan atau menggunakan banyaknya kegiatan yang terputus-putus, diantaranya yaitu orang yang dapat memakai arti khayalan, mengamati dan mengingat apa yang akan dikaitkan dengan skemata pembaca.

Setiap yang melakukan kegiatan membaca harus mampu menggerakkan penglihatan dengan teliti, mesti fokus dalam kegiatan membaca agar informasi atau amanat yang tertera di bacaan dapat dipahami dengan baik. Dalam aktivitas literasi, secara general pembaca banyak sekali yang belum mampu melakukan kegiatan literasi dengan benar dan baik, belum tahu kejelasan metode membaca tepat serta cepat, bahkan cara memprediksi ketepatan serta kecepatan dalam kegiatan membaca.

Dalam aktivitas pembelajaran mengajar dalam mata pelajaran bahasa Indonesia di lembaga pendidikan tingkat dasar mempunyai esensi penting sekali untuk peserta didik, karena melalui proses pembelajaran pada mata pelajaran yaitu bahasa Indonesia di tingkat Dasar yang proses awalnya diberikan kemampuan dasar berbahasa Indonesia. Kegiatan yang begitu urgen dalam bidang pembelajaran bahasa Indonesia diantaranya pembelajaran membaca. Tanpa adanya daya mampu dalam membaca di waktu kecil, dalam waktu yang akan datang anak dapat mengalami kesulitan belajar pada tingkat yang lebih tinggi. Maka ada yang mesti kita ingat, bahwa penting sekali membaca bagi siswa, seorang pendidik mesti tepat dalam menggunakan metode dalam aktivitas pembelajaran yang dipakai dalam proses kegaiatan belajar mengajar. Sehingga dengan metode tersebut dapat menghasilkan peningkatan motivasi belajar pada siswa dan mempermudah siswa dalam mencerna apa yang akan disampaikan guru (Fathurrohman 2010). 
Sebagian besar guru masih belum memakai metode dan strategi dalam aktivitas belajar mengajar kreatif dan inovatif, hal ini menjadikan proses aktivitas belajar dan mengajar yang tidak efektif, siswa kurang merespon materi yang diajarkan, cenderungnya kegiatan pengajaran cenderung membosankan. Dalam pembelajaran membaca, motivasi sangat penting dimana minat siswa dalam membaca dapat meningkat. Adapun cara dan jenis menumbuhkan minat dan dorongan untuk belajar dalam proses pembelajaran sangatlah bermacam-macam, hal ini mengakibatkan guru harus lebih selektif dan mesti cermat dalam menumbuhkan serta memberikan motivasi bagi siswa. pola dan metode yang ada dalam upaya pengembangan minat dan dorongan aktivitas belajar peserta didik terhadap kegiatan membaca yaitu dengan pemberian bobot angka, hadiah, dan pujian (Sardiman 2011).

Berkaitan dengan uraian di atas, peneliti melakukan tes membaca kepada peserta didik SDN 4 Cisande Kabupaten Sukabumi, dengan waktu hari Senin, 27 Februari 2017, yang memiliki orientasi dalam proses mengetahui sudah jauhkah kemampuan membaca siswa. Melalui tes membaca, peneliti menyadari akan rendahnya tingkat pengetahuan dan kemampuan siswa terhadap membaca di kelas 1 SDN 4 Cisande Kabupaten Sukabumi. Hal tersebut bisa tergambarkan dari evaluasi yang diperoleh siswa masih dibawah indikator keberhasilan Kriteria dan Ketuntasan Minimal (KKM) yang telah ditentukan.

Sehubungan dengan data yang penulis paparkan, permasalahan membaca yang terjadi di lembaga pendidikan tingkat sekolah dasar, yaitu SDN 4 Cisande Kabupaten Sukabumi bahwa dari 34 siswa, hanya $20,5 \%$ atau 7 siswa sudah memiliki kemampuan membaca secara benar, baik juga lancar. Hal ini dikarenakan cara serta strategi pada aktivitas belajar mengajar masih memiliki sifat yang konvensional dan belum kreatif dan inovatif, rendahnya sumber aktivitas pembelajaran yang telah dimiliki siswa di sekolah maupun di rumah, ruang perpustakaan yang ada di sekolah penulis teliti masih sangat rendah dalam ketersediaan sumber belajar dan sarana pembelajaran sehingga membatasi siswa untuk membaca mandiri.

\section{MATERI DAN METODE}

\section{Materi}

\section{Metode Guide Reading}

Metode Guide reading merupakan metode dalam kegiatan pembelajaran terbimbing guna membantu siswa dalam menggunakan strategi pembelajaran membaca secara mandiri. Tujuan utama dari metode guide reading yaitu guna memberikan kemampuan siswa belajar bagaimana menggunakan strategi membaca individual dengan sukses. Metode guide reading (GR) bertujuan melakukan kegiatan pelatihan kepada para siswa guna menjadi pembelajar mandiri dan aktif (active learners), lebih fokus pada persoalan yang dihadapi, dan tentunya menjadikan peserta didik tidak memiliki rasa jenuh juga bosan dalam menempuh pembelajaran membaca. Metode guide reading (GR) juga sangat efektif, variatif dan mampu memacu kreativitas pendidik dan peserta didik. Pembelajaran di kelas menjadi lebih senang dan tentunya sangat berkesan. Dengan model pembelajaran guide reading, diharapkan dapat menciptakan aktivitas belajar dan mengajar yang sangat kondusif. Model dalam pembelajaran yang bertujuan dalam pemberian bantuan kepada peserta didik supaya lebih fokus serta dengan mudah 
memiliki pemahaman akan pembelajaran yang disampaikan (Yunus 2012).

Langkah-langkah yang bisa dilakukan untuk menerapkan metode guide reading (GR) sebagai berikut.

a. Pemilihan dan penentuan teks yang akan dibaca.

b. Siswa terbagi dalam pembuatan kelompok-kelompok kecil (4-5 orang).

c. Setiap siswa yang membaca teks telah ditentukan dengan tiga tahapan, yaitu dibaca sendiri satu kali, dibaca pelan/lembut, dan dibaca didalam hati.

d. Siswa meminta dan mencari petunjuk informasi selanjutnya tentang bagaimana metode yang diimplementasikan dalam aktivitas membaca beberapa kata kepada teman sejawatnya sebagai bahan dan acuan untuk melakukan diskusi awal dengan kelompoknya.

e. Guru menyiapkan kegiatan diskusi yang kecil sebagai bentuk eksplorasi yang meliputi phonic concept dan wholelanguage learning. Selanjutnya pendidik memberikan pengawasan kemampuan reading dengan cara reading/repetition.

f. Guru selanjutnya boleh menggunakan gambar dalam upaya penunjang arti.

Langkah-langkah metode guide reading dapat di implementasikan sesuai dengan kegiatan berikut.

1. Tahap prabaca

Memilih buku, memperkenalkan buku, buatlah prediksi, berusaha menstimulus skemata terhadap anak juga membuat papan informasi.

2. Tahap membaca

Membaca dengan lirih pada halaman pertama, mengkoreksi dan melakukan penyusunan ulang prediksi, serta melanjutkan dalam melakukan sebuah kegiatan membaca serta melakukan kegiatan memprediksi.

3. Tahap pasca baca

Mendiskusikan cerita, membaca prediksi serta membuat daftar kosakata.

Metode guide reading memiliki orientasi guna memberikan pelatihan terhadap siswa sehingga mampu menjadi pembelajar mandiri dan aktif (aktive learners), lebih fokus pada persoalan yang dihadapi, dan tentunya tidak membuat bosan siswa dalam menempuh pembelajaran membaca. Metode guide reading juga sangan efektif, variatif dan mampu memacu kreativitas pendidik serta peserta didik. Pembelajaran dikelas menjadi begitu terasa menyenangkan dan sangat berkesan bagi siswa, sehingga diharapkan dapat menciptakan kegiatan pembelajaran kondusif. Model dalam kegiatan belajar dan mengajar ini juga memiliki tujuan guna membuat siswa sangat fokus dan juga sangat mudah untuk mendapatkan pemahaman pembelajaran pada saat dalam kelas serta memfokuskan perhatian siswa, sehingga siswa memiliki konsentrasi yang penuh serta memiliki pemahaman akan pelajaran pada saat pembelajaran dilakukan dikelas (Asra dan Sumiati 2011).

\section{Motivasi Belajar Siswa Dalam Teori Membaca Nyaring}

Motivasi berawal dari kata 'motif', memiliki maksud yaitu kekuatan yang terdapat dan tersimpan dalam individu sebagai penggerak dalam melakukan sebuah kegiatan tertentu guna tercapainya sebuah tujuan yang diharapkan. Bahkan menurut McDonald, motivasi adalah bentuk energi yang terdapat dan tersimpan dalam diri individu sebagai perubahan yang dapat ditandai adanya feeling dan berawal dari anggapan, pendapat atas adanya sebuah tujuan (Sardiman 2011). 
Motivasi asal kata yang dalam bahasa latin movere, memiliki sebuah arti menggerakkan, motivasi juga dapat dijelaskan melalui perilaku tertentu. Dalam pengertian ini, siswa memiliki suatu usaha dalam upaya mencapai apa yang menjadi tujuan serta harapan yang dapat dirangsang oleh kegunaan serta kebaikan yang akan didapatkan (Kartajaya 2010).

Motivasi merupakan sebuah daya yang kuat terdapat serta tersimpan dalam individu secara internal dan eksternal, mampu mendorong seseorang dalam mencapai apa yang menjadi sebuah tujuan awal yang menjadi harapan dan target. Motivasi menjadi sebuah kekuatan mental yang mendorong individu maupun orangorang sebagai anggota dari sebuah masyarakat. Umumnya motivasi memiliki tujuan untuk membangkitkan individu supaya muncul gairah keinginan serta kemauan dalam melakukan sesuatu. Jadi, motivasi ialah suatu rangkaian usaha berbentuk kekuatan yang berfungsi mendorong individu dalam melakukan sesuatu guna tercapainya sebuah tujuan yang diinginkan. Diantara indikator pencapaian keberhasilan sebuah pendidikan yang secara mikro ada dalam tataran pembelajaran dikelas yaitu apabila seorang guru memiliki kemampuan untuk menggugah motivasi akan adanya keinginan belajar yang besar pada diri siswa yang ada dikelas.

Motivasi dalam kegiatan belajar merupakan faktor kejiwaan yang memiliki sifat non intelektual,sebagai penumbuhan kegairahan untuk belajar, memiliki kecintaan serta semangat dalam melakukan kegiatan belajar. Motivasi dan keinginan dalam kegiatan belajar menajdi sebuah kekuatan terbesar yang terdapat pada individu sifatnya instrinsik serta ekstrinsik, yang mampu menghasilkan kegiatan belajar, memberi acuan serta memberikan jaminan dalam terjadinya kegiatan belajar dan mengajar serta berfungsi sebagai proses penumbuhan beberapa sifat baik yang positif, diantaranya adanya kegairahan dalam belajar, memiliki kesenangan dalam belajar sehingga bertambahnya ilmu pengetahuan juga keterampilan (Sumantri et al. 2015).

Sumantri et al. (2015) juga menyebutkan bahwa motivasi belajar juga merupakan dorongan yang ada dari dalam serta luar pada diri siswa yang sedang pada saat proses pembelajaran sehingga munculnya sebuah perubahan akhlak dan karakter dengan indikator sebagai berikut.

a. Memiliki hasrat serta memiliki keinginan untuk sukses dan berhasil.

b. Adanya kekuatan serta sangat butuh dalam belajar.

c. Memiliki sebuah harapan besar dan citacita pada masa yang akan datang.

d. Penghargaan yang ada dalam kelompok.

e. Terdapat kegiatan menarik yang terjadi pada saat belajar.

f. Adanya lingkungan yang kondusif, akhirnya siswa memiliki kemampuan belajar dengan baik.

Membaca nyaring merupakan aktivitas dalam membaca menggunakan intonasi suara juga aktivitas dalam mengutarakan tanda-tanda bunyi bahasa dengan bunyi suara yang cukup keras. Membaca nyaring memiliki orientasi agar individu mampu dalam memakai kata-kata sangat tepat, membaca tanpa mesti terus-menerus melihat materi bacaan, membaca memakai intonasi serta lagu tepat serta jelas. Membaca nyaring juga merupakan sebuah kegiatan yang bisa disebut alat bagi seorang guru, siswa serta individu yang membaca secara bersama-sama dengan yang lainnya atau pendengar untuk memiliki daya 
tangkap, memiliki pemahaman akan informasi, daya pikir, serta perasaan seorang pengarang (Dalman 2014).

Pada aktivitas membaca nyaring, dibutuhkan penglihatan serta kemampuan untuk mengingat, serta ingatan yang aktif dalam pendengaran serta kemampuan berpikir yang terkait dengan menggunakan otot-otot kita. Membaca nyaring menuntut setiap individu dalam melakukan kegiatan membaca mestilah mempunyai kecepatan mata yang tinggi serta pandangan mata yang jauh kedepan, sebab seorang pembaca mesti meninjau serta melihat pada materi bacaan guna memelihara kontak penglihatan individu dengan orang yang mendengarkannya.

Membaca nyaring bertujuan supaya individu memiliki kemampuan dalam mempergunakan pengucapan yang baik, benar serta sesuai dengan bahan bacaan, melakukan aktivitas membaca tanpa mesti harus melihat materi bacaan, membaca memakai intonasi nada serta lagu yang tepat juga jelas (Tarigan 2013).

\section{Metode}

Desain penelitian yaitu pendekatan kuantitatif, yaitu suatu pembuktian atau pengujian yang dimulai dengan teori-teori atau hipotesis yang memakai metode korelasi fungsional. Penelitian yang korelasional dapat dijelaskan sebagai sebuah gambaran dalam sebuah pendekatan yang umum, dalam kegiatan penelitian yang mesti berfokus pada penaksiran antara dua variabel yang akan muncul secara alami (Emzir 2011). Penelitian ini memiliki hipotesis hubungan dua variabel yang memiliki orientasi dalam upaya mengetahui hubungan variabel yang bebas atas variabel terikat.

Teknik pengumpulan data melalui penggunaan tes, angket dan dokumentasi.
Dalam penelitian ini digunakan persyaratan analisis data yaitu uji normalitas dan linearitas. Teknik dalam analisis data supaya dapat diketahui seberapa besar signifikansi penggunaan metode guide reading (variabel $\mathrm{X}$ ) atas motivasi belajar siswa (variabel $\mathrm{Y}$ ), dengan cara uji korelasi melalui persamaan regresi, koefisien determinasi serta uji t.

Penelitian dilaksanakan di Sekolah Dasar Negeri 4 Cisande Kecamatan Cicantayan Kabupaten Sukabumi dalam Pembelajaran mata pelajaran Bahasa Indonesia. Target populasi yang diteliti adalah 34 siswa dari kelas satu (1). Sampel yang diambil pada penelitian ini adalah 31 siswa di kelas satu (1).

\section{Teknik Pengumpulan Data Tes}

Tes pada penelitian yang dilakukan berupa lembar kerja diperuntukkan kepada siswa berupa pertanyaan seputar proses/tahapan dalam membaca, yaitu meliputi proses prabaca, tahap membaca, dan proses pascabaca

\section{Angket}

Data harus komprehensif, peneliti menggunakan angket yang disebarkan kepada siswa. Penyebaran angket dilakukan sebagai proses serta dalam rangka mengetahui seberapa besarkah signifikansi dari pengaruh metode Guide reading terhadap motivasi belajar siswa dalam aktivitas pembelajaran membaca yang dilakukan oleh siswa kelas satu (I) SDN 4 Cisande Kabupaten Sukabumi.

\section{Dokumentasi}

Dalam penelitian ini, dokumentasi diharapkan mendapatkan data tentang nama maupun nilai siswa yang nantinya dijadikan data untuk meneliti homogenitas kelas di SDN 4 Cisande Kabupaten Sukabumi. 


\section{HASIL DAN PEMBAHASAN}

\section{Hasil}

Deskripsi data penelitian yang disajikan adalah untuk menjelaskan secara umum bagaimana gambaran dalam penyebaran data di lapangan. Data yang diambil sebagai deskripsi penelitian ini merupakan data yang diambil variabel $\mathrm{X}$ metode guide reading serta variabel $Y$ yaitu motivasi belajar yang ada pada siswa. Peneliti mengumpulkan data dari dua sumber, yakni perolehan tes berupa LKP metode guide reading dan angket motivasi belajar siswa yang ada dan terlaksana saat pembelajaran membaca nyaring. LKP yang dibuat penulis berdasarkan tahapan pada proses terlaksananya aktivitas pembelajaran membaca dengan penggunaan metode guide reading (sebagai variabel $\mathrm{X}$ ) yang dikerjakan oleh 31 siswa. Sedangkan angket yang disusun oleh penulis terdiri dari 30 pertanyaan mengenai motivasi belajar yang ada pada siswa (sebagai variabel Y) yang disebar ke 31 siswa sebagai responden.

\section{Deskripsi data metode Guide reading (variabel X)}

Berdasarkan perolehan nilai lembar kerja proses (LKP) yang telah diberikan kepada siswa seperti pada Tabel 1. Pada tabel 1, hasil perhitungan lembar kerja proses (LKP) yang berisi 3 item pertanyaan, didapatlah rentang skor minimum 128 dan skor maksimum 288. Skor rata-rata (mean) yaitu 228.90. Dari data yang sudah diperoleh bahwa simpangan baku yakni sebesar 26.066 .

Tabel 1 Deskriptif data metode guide reading $(\mathrm{X})$

\begin{tabular}{|c|c|c|c|c|c|c|c|c|c|c|}
\hline & $\mathrm{N}$ & Range & Minimum & Maximum & Sum & Mean & $\begin{array}{c}\text { Std. } \\
\text { Deviation }\end{array}$ & Variance & Skewness & Kurtosis \\
\hline & Statistic & Statistic & Statistic & Statistic & Statistic & Statistic $\begin{array}{c}\text { Std. } \\
\text { Error }\end{array}$ & Statistic & Statistic & Statistic $\begin{array}{c}\text { Std. } \\
\text { Error }\end{array}$ & $\begin{array}{c}\text { Statistic } \\
\text { Error }\end{array}$ \\
\hline Metode GR & 31 & 106 & 182 & 288 & 7096 & 228.904 .682 & 26.066 & 679.424 & . $188 \quad .421$ & $.222 \quad .821$ \\
\hline $\begin{array}{l}\text { Valid N } \\
\text { (listwise) }\end{array}$ & 31 & & & & & & & & & \\
\hline
\end{tabular}

Dari data di atas, dapat dihitung panjang kelas interval dengan rumus:

$$
P=R / K
$$

Keterangan: $\mathrm{P}=$ Panjang interval; $\mathrm{R}=$ Rentang nilai (Skor max-Skor min); K = Banyak kelas $(1+3,3 \log N$ ); $\mathrm{N}=$ Jumlah Responden; 3,3 = Konstanta.

Diketahui:

$$
\begin{array}{ll}
\mathrm{R} & =288-182=106 \\
\mathrm{~K} & =1+3.3 \log 31=5.92
\end{array}
$$

Maka: $\mathrm{P}=\mathrm{R} / \mathrm{K}=106 / 5.92=17.91$

Dengan demikian panjang interval adalah 17.91. Agar memudahkan perhitungan maka bilangan angka 17.91 dibulatkan menjadi 18.
Selanjutnya dapat dihitung distribusi frekuensi variabel X sebagaimana tertera dalam tabel 2. Berdasarkan tabel 2, dapat diketahui frekuensi skor tertinggi yaitu 11, berada pada kelas interval antara 218 hingga 235, dengan skor rata-rata (mean) yaitu 228.90. Apabila perolehan skor rata-rata menjadi acuan untuk patokan batas skor untuk variabel $\mathrm{X}$, ternyata skor responden yang dibandingkan memperoleh skor lebih kecil dari skor rata-rata dapat dihitung sebanyak 9 responden, yang setara pada 29.03\%. Sedangkan hasil yang didapatkan pada skor yang berada di atas skor rata-rata 
berjumlah 11 responden, artinya sesuai pada hasil $35.48 \%$. Dengan membandingkan harga persentase tersebut bisa dibuat penyataan kalau ternyata perolehan skor variabel $\mathrm{X}$ dapat dikategorikan sedang.

Tabel 2 Distribusi frekuensi metode guide reading $(\mathrm{X})$

\begin{tabular}{|c|c|c|c|c|}
\hline \multirow{2}{*}{$\begin{array}{l}\text { No } \\
1 .\end{array}$} & \multicolumn{2}{|c|}{$\begin{array}{c}\text { Kelas } \\
\text { Interval }\end{array}$} & \multirow{2}{*}{$\begin{array}{r}\text { Frekuensi } \\
\text { Kumulatif } \\
5\end{array}$} & \multirow{2}{*}{$\begin{array}{l}\text { Frekuensi } \\
\text { Relatif } \\
(\%) \\
16\end{array}$} \\
\hline & 182 & 199 & & \\
\hline 2. & 200 & - 217 & 4 & 13 \\
\hline 3. & 218 & - 235 & 11 & 35 \\
\hline 4. & 236 & - 253 & 8 & 26 \\
\hline 5. & 254 & - 271 & 0 & 0 \\
\hline 6. & 272 & - 289 & 3 & 10 \\
\hline \multicolumn{3}{|c|}{ Jumlah } & 31 & 100 \\
\hline
\end{tabular}

\section{Metode Guide Reading (X)}

Berdasarkan Gambar 1, perolehan nilai terbanyak atau berada pada urutan frekuensi paling atas yaitu dengan nilai ratarata 220 terdapat di kelas interval 218-235. Berikutnya, urutan frekuensi ke 5 pada hasil perolehan nilai rata-rata 240 berada pada

kelas interval 236-253. Pada urutan frekuensi ke 4 dengan hasil perolehan pada nilai rata-rata 180 terdapat diposisi kelas interval 182-199. Pada urutan frekuensi ke 3 dengan perolehan nilai rata-rata 200 yang ada pada posisi kelas interval 200-217.
Adapun urutan frekuensi terendah dengan nilai rata-rata 280 yang ada di kelas interval 272-288.

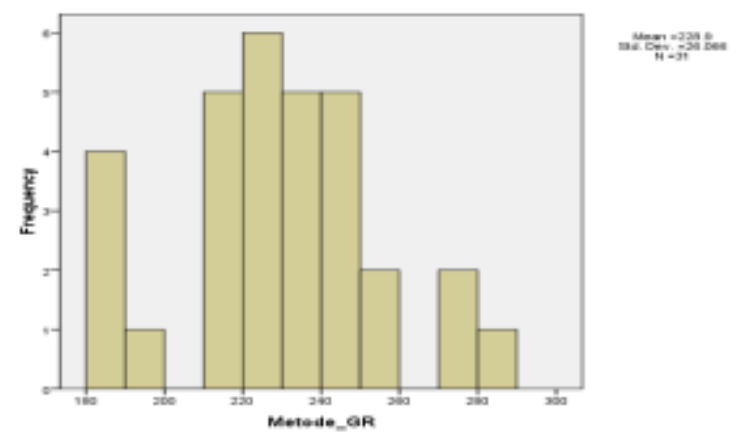

Gambar 1 Data metode guide reading (variabel $\mathrm{x}$ )

\section{Deskripsi Data Motivasi Belajar Siswa (variabel Y)}

Sesuai pada hasil angket yang telah disebar ke 53 siswa, maka dapat dideskripsikan hasil data yang tertera di tabel 3. Dari data tabel 3, dapat dihitung panjang atas kelas interval dengan rumus:

$$
P=R / K
$$

Keterangan: $\mathrm{P}=$ Panjang interval; $\mathrm{R}=$ Rentang nilai (Skor max-Skor min); K = Banyak kelas $(1+3,3 \log \mathrm{N})$; $\mathrm{N}=$ Jumlah Responden; 3,3 = Konstanta

Diketahui:

$\mathrm{R}=85-70=15$

$\mathrm{K}=1+3.3 \log 31=5.92$

Maka: $\mathrm{P}=\mathrm{R} / \mathrm{K}=15 / 5.92=2.53$

Dengan demikian panjang interval adalah 2.53. Agar memudahkan perhitungan maka bilangan angka 2.53 dibulatkan menjadi 3.

Tabel 3 Deskriptif data motivasi belajar siswa (Y)

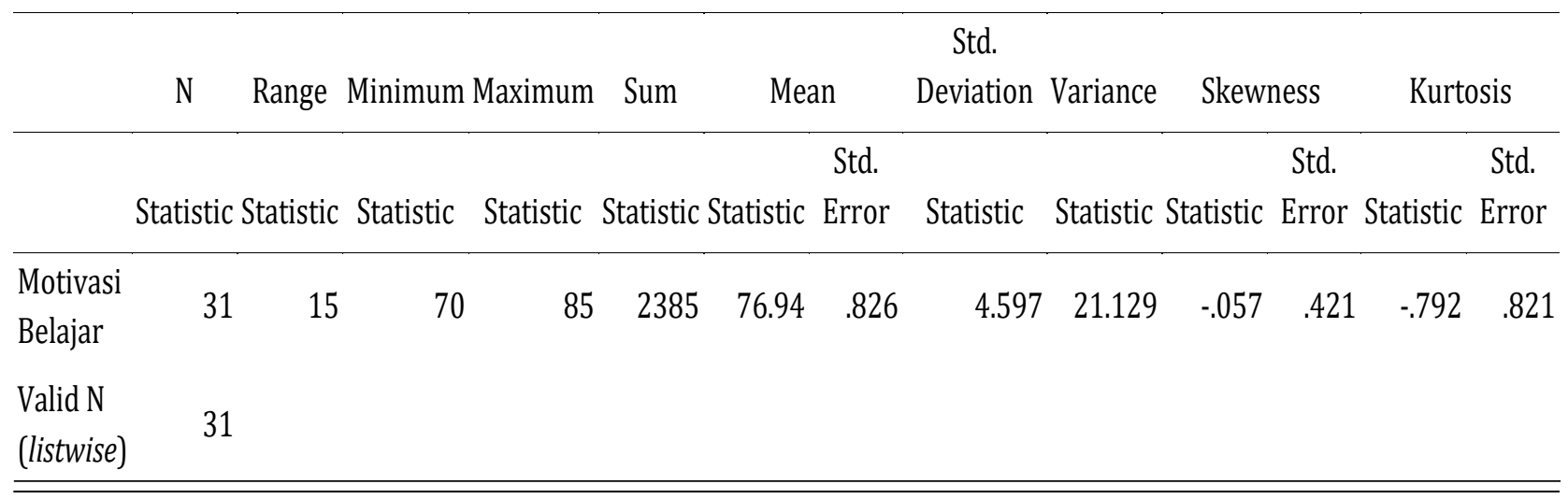


Selanjutnya dapat dihitung distribusi frekuensi variabel Y sebagaimana terlihat di tabel 4.

Tabel 4 Distribusi frekuensi motivasi belajar siswa (Y)

\begin{tabular}{|c|c|c|c|c|}
\hline No & \multicolumn{2}{|c|}{$\begin{array}{c}\text { Kelas } \\
\text { Interval }\end{array}$} & \multirow{2}{*}{$\begin{array}{l}\text { Frekuensi } \\
\text { Kumulatif } \\
6\end{array}$} & \multirow{2}{*}{$\begin{array}{r}\begin{array}{r}\text { Frekuensi } \\
\text { Relatif }(\%)\end{array} \\
19\end{array}$} \\
\hline 1. & 70 & - 72 & & \\
\hline 2. & 73 & -75 & 10 & 32 \\
\hline 3. & 76 & -78 & 0 & 0 \\
\hline 4. & 79 & - 81 & 12 & 39 \\
\hline 5. & 82 & -84 & 0 & 0 \\
\hline 6. & 85 & - 87 & 3 & 10 \\
\hline \multicolumn{3}{|c|}{ Jumlah } & 31 & 100 \\
\hline
\end{tabular}

Berdasarkan tabel 4 dapat diketahui frekuensi skor tertinggi yaitu 12, posisinya terdapat diposisi kelas interval antara 79 hingga 81, skor rata-rata (mean) hasilnya sebesar 76,94. Apabila hasil yang sudah didapatkan pada skor rata-rata tersebut menjadi bahan patokan batas skor untuk variabel $\mathrm{Y}$, ternyata perbandingan skor responden yang didapatkan bahwa skor lebih kecil dari skor rata-rata dapat dihitung sebanyak 16 responden, terdapat di posisi 51.61\%. Sedangkan hasil yang didapatkan skor yang berada pada posisi atas skor ratarata ada 3 responden, artinya ada diposisi 9.68\%. Dengan membandingkan harga persentase tersebut dinyatakan ketetapan bahwa perolehan skor variabel $\mathrm{Y}$ dapat dikategorikan sedang.

\section{Motivasi Belajar Siswa (Y)}

Data variabel Y disajikan dalam histogram pada Gambar 2.
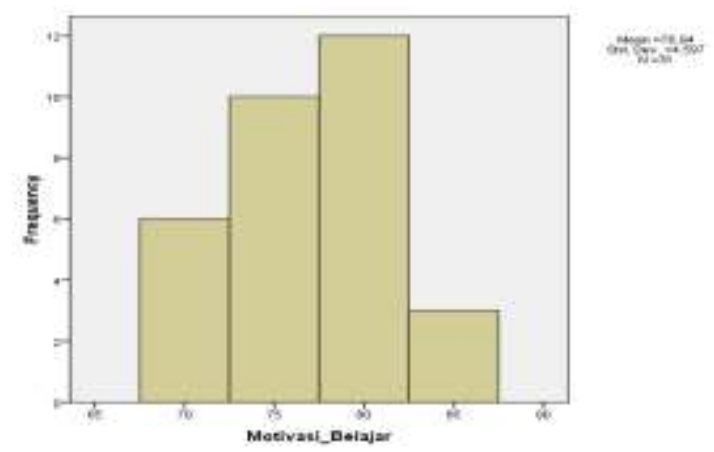

Gambar 2 Data motivasi belajar siswa (variable y)

Berdasarkan Gambar 2, diketahui perolehan nilai terbanyak yaitu 12 dengan nilai rata-rata 80 pada kelas interval 79-81. Berikutnya perolehan nilai 75 sebanyak 10 berada di kelas interval 73-75. Untuk perolehan nilai 70 sebanyak 6 yang ada di kelas interval 70-72. Sedangkan perolehan nilai 85 sebanyak 3 orang ada di kelas interval 85-87.

\section{Pengujian Prasyarat Analisis Data Uji Normalitas}

Berdasarkan hasil perhitungan KolmogorovSmirnov, jika nilai p valie Sig seluruh variabel hasilnya memiliki kelebihan besar dari 0.05 . ini artinya menunjukkan penerimaan $\mathrm{H}_{\mathrm{a}}$, bahwa hasil yang dapat dibuat kesimpulan ternyata seluruh variabel berdistribusi normal. Adapun hasil pengujian normalitas dilakukan pada peneliti dengan metode Kolmogorov-Smirnov, sesuai tabel 5. Berdasarkan tabel 5, diperoleh taraf signifikansi dari jumlah siswa 31 adalah 0.188 . Dengan demikian, diperoleh nilai $p_{\text {value }}$ Sig seluruh variabel dikatakan hasilnya lebih besar yaitu 0,05. Artinya dapat ditunjukkan bahwa penerimaan $\mathrm{H}_{\mathrm{a}}$, dapat dideskripsikan bahwa semua variabel berdistribusi normal. 
Tabel 5 Data hasil uji normalitas

\begin{tabular}{llr}
\hline \multicolumn{2}{c}{ One-Sample Kolmogorov-Smirnov Test } \\
\hline & & $\begin{array}{c}\text { Unstandardized } \\
\text { Residual }\end{array}$ \\
\hline $\mathrm{N}$ & Mean & 31 \\
Normal & Std. & .0000000 \\
Parameters & & \\
& Deviation & .195 \\
Most Extreme & Absolute & .104 \\
Differences & Positive & -.195 \\
& Negative & 1.087 \\
Kolmogorov-Smirnov Z & .188 \\
Asymp. Sig. (2-tailed)
\end{tabular}

Keterangan: $\mathrm{a}=$ Test distribution is Normal.

\section{Uji Linearitas}

Adapun hasil pengujian linearitas terdapat pada Tabel 6.

Berdasarkan data tabel 6, menunjukkan nilai $F_{\text {hitung }}=0.545$ lebih kecil dari $F_{\text {tabel }}=1.85$ dengan nilai signifikansi 0.494 lebih besar dari 0.05. Maka pengaruh variabel metode Guide reading $(\mathrm{X})$ terhadap variabel motivasi belajar siswa (Y) dikatakan linear yang artinya bahwa ada pengaruh signifikansi variabel $\mathrm{X}$ terhadap variabel Y.

Tabel 6 Data hasil uji linearitas

\begin{tabular}{|c|c|c|c|c|c|c|c|}
\hline \multicolumn{8}{|c|}{ ANOVA Table } \\
\hline & & & Sum of & & Mean & & \\
\hline & & & Squares & $\mathrm{df}$ & Square & $\mathrm{F}$ & Sig. \\
\hline Variabel_Y* $^{*}$ & \multicolumn{2}{|c|}{ Between (Combined) } & 546.371 & 25 & 21.855 & 1.249 & .440 \\
\hline \multirow[t]{4}{*}{ Variabel_X } & Groups & Linearity & 9.533 & 1 & 9.533 & .545 & .494 \\
\hline & & $\begin{array}{l}\text { Deviation from } \\
\text { Linearity }\end{array}$ & 536.838 & 24 & 22.368 & 1.278 & .428 \\
\hline & \multicolumn{2}{|c|}{ Within Groups } & 87.500 & 5 & 17.500 & & \\
\hline & \multicolumn{2}{|l|}{ Total } & 633.871 & 30 & & & \\
\hline
\end{tabular}

\section{Pengujian Hipotesis Statistika}

Pengujian hipotesis merupakan inti dari permasalahan dalam penelitian. Tahapantahapan dipakai dalam memberikan jawaban hasil kesimpulan sementara (hipotesis) penelitian adalah dengan menggunakan tahapan analisis statistik, yaitu bisa menggunakan proses yang dilalui analisis regresi dan analisis korelasi.

\section{Persamaan Regresi}

Analisis regresi diketahui bisa dipakai dalam menguji bagaimana variabel dependen (Y) dapat diprediksi melalui variabel independen (X). Adapun data yang diperoleh pada analisis regresi terdapat pada Tabel 7.

Tabel 7 Data menentukan persamaan regresi

Coefficients $^{\mathrm{a}}$

Unstandardized Standardized

Coefficients Coefficients

Std.

Model B Error Beta

1 (Constant) 71.9857 .486

Metode_GR $\quad .022 \quad .032$ .123

a. Dependent variable: motivasi belajar 
Dari tabel 7 diperoleh harga komponen a $=71.985$, dan harga komponen $\mathrm{b}=0.022$. harga a merupakan besarnya harga Y apabila harga $X=0$, sedangkan harga $b$ adalah nilai koefisien regresi Y atas X. Berdasarkan hasil dari perhitungan regresi sederhana maka diperoleh harga persamaan regresi sebagaimana dirangkum pada tabel 8 yang memberikan gambaran hubungan variabel $\mathrm{X}$ dengan variabel Y. Konstanta pada komom B $=71.985$ dan variabel $\mathrm{X}=0.022$.

Tabel 8 Persamaan Regresi variabel X dengan variabel Y

\begin{tabular}{ccc}
\hline a & 71.921 & Pers. Regresi \\
\cline { 3 - 3 } b & 0.022 & $\mathrm{X}=71.985+0.022 \mathrm{Y}$ \\
\hline
\end{tabular}

Persamaan regresi yang dihasilkan sebesar $\mathrm{Y}=71.985+0.022 \mathrm{X}$. Dari data tertera yaitu pada tabel 8 menggambarkan prediksi perolehan $\mathrm{Y}$ bertambah sebesar $0.022 \mathrm{X}$.

\section{Koefisien Determinasi}

Koefisien determinasi adalah kuadrat dari koefisien korelasi yang dikalikan dengan 100. Koefisien determinasi memiliki pengertian bahwa besarnya persentase varians variabel yang satu dapat dipastikan oleh varians variabel lain. Artinya, koefisien determinasi dapat dipakai dalam proses mengukur seberapa jauh variabel-variabel bebas mampu menjelaskan determinasi yang ditentukan dengan $R$-Squer.

Berdasarkan Tabel 9, menunjukkan bahwa hubungan (korelasi) antara metode Guied Reading dengan motivasi belajar siswa positif, yaitu: $r=0.123$. Definisi yang positif adalah hubungan yang ada antara variabel $X$ dan variabel Y searah. Maksud searah di sini, semakin sering penggunaan metode guide reading, maka semakin meningkat motivasi belajar siswa.Kontribusi yang disumbangkan metode guide reading $(\mathrm{X})$ terhadap motivasi belajar siswa $(\mathrm{Y})$ sebesar $0.123^{2}=0.015$ setara dengan $1.5 \%$.

Tabel 9 Menentukan koefisien determinasi

\begin{tabular}{|c|c|c|c|c|}
\hline \multicolumn{5}{|c|}{ Model Summaryb } \\
\hline & & $\mathrm{R}$ & Adjusted & $\begin{array}{c}\text { Std. Error } \\
\text { of the }\end{array}$ \\
\hline Model & $\mathrm{R}$ & Square & R Square & Estimate \\
\hline 1 & 23 & .015 & -.019 & 4.640 \\
\hline
\end{tabular}

Keterangan: a. Predictors: (Constant), Metode_GR; b. Dependent Variable: Motivasi_Belajar

\section{Uji t}

Uji $\mathrm{t}$ adalah tes statistik yang dapat dipakai dalam pengujian perbedaan atau kesamaan dua kondisi/perlakuan atau dua kelompok yang berbeda dengan prinsip memperbandingkan rata-rata (mean) kedua kelompok/perlakuan itu. Uji $t$ ini dideskripsikan dalam proses mengetahui besarnya pengaruh metode Guide reading terhadap motivasi belajar siswa dalam pembelajaran membaca nyaring. Diawali dengan menentukan hipotesis nol dan hipotesis alternatif.

Ho : Tidak terdapat pengaruh antara variabel $X$ dengan variabel $Y$

$\mathrm{Ha}$ : Terdapat pengaruh antara variabel $\mathrm{X}$ dengan variabel $Y$

Kriteria signifikansi pengaruh antara variabel $\mathrm{X}$ dengan variabel $\mathrm{Y}$ dikatakan signifikan apabila $p_{\text {value }} \operatorname{Sig}<0.05$. Adapun data yang diperoleh tertera pada tabel 10 .

Tabel 10 Data Uji t

\begin{tabular}{|c|c|c|c|c|}
\hline \multicolumn{5}{|c|}{ Coefficients $^{a}$} \\
\hline \multirow{2}{*}{ Model } & $\begin{array}{r}\text { Unstand } \\
\text { Coeffic }\end{array}$ & $\begin{array}{l}\text { ardized } \\
\text { ients }\end{array}$ & $\begin{array}{l}\text { Standardized } \\
\text { Coefficients }\end{array}$ & \multirow{2}{*}{ t Sig. } \\
\hline & B & $\begin{array}{l}\text { Std. } \\
\text { Error }\end{array}$ & Beta & \\
\hline 1 (Constant) & 71.985 & 7.486 & & 9.616 .000 \\
\hline Metode GR & .022 & .032 & .123 & .665 .511 \\
\hline
\end{tabular}


Berdasarkan data tabel 10, hasil analisis korelasi antara $\mathrm{X}$ dengan $\mathrm{Y}$ menghasilkan koefisien korelasi $\mathrm{r}_{\mathrm{y}} \mathrm{x}_{1}=0.123$. Koefisien signifikansi thitung $=0.665$, sedangkan harga tabel pada taraf kesalahan $5 \%(0,05)=0.725$. Artinya maka pernyataan dapat ditulis bahwa, thitung $<$ tabel $_{\text {tan }}(0.665<0.725)$. Dari perolehan data yang sudah didapatkan dapat disimpulkan terima $\mathrm{H}_{\mathrm{o}}$ dan tolak $\mathrm{H}_{\mathrm{a}}$. Karena itu hipotesis penelitian menyatakan "tidak terdapat pengaruh antara variabel $\mathrm{X}$ dengan variabel Y".

\section{Pembahasan}

Penelitian yang dilakukan yaitu jenis penelitian korelasi fungsional dengan penggunaan proses mengetahui seberapa besarkah signifikansi variabel metode Guide reading $(\mathrm{X})$ terhadap variabel motivasi belajar siswa (Y) di kelas I SDN 4 Cisande Kabupaten Sukabumi. Dengan jumlah sampel berjumlah 31 siswa. Pengujian hipotesis dalam pengujian ini menggunakan uji signifikansi yaitu melalui uji t. Sebelum uji t dilakukan, harus dilakukan distribusi data terlebih dahulu melalui analisis deskriptif, uji prasyarat yang meliputi uji normalitas serta uji linearitas, serta analisis data meliputi persamaan regresi dan koefisien determinasi.

Berdasarkan hasil data uji normalitas dan uji linearitas, memiliki tujuan guna mengetahui apakah data memiliki distribusi normal atau tidak serta bersifat linear atau tidak. Berdasarkan perhitungan menggunakan program aplikasi SPSS 16.0 diperoleh data signifikansi $0.188>0.05$ yang berarti memiliki nilai berdistribusi normal. Data dikatakan berdistribusi normal atau tidaknya dapat dilihat dari nilai signifikansinya harus lebih besar dari 0.05.sedangkan uji linearitas memiliki nilai signifikansi 0.428 yang bermakna bahwa data tersebut linear karena lebih besar dari
0.05. Serta nilai $F_{\text {hitung }}=0.545$ lebih kecil dari $\mathrm{F}_{\text {tabel }}=1.85$ dengan nilai signifikansi 0.494 yang berarti data memiliki hubungan yang linearitas atau data bersifat linear. Data dikatakan bersifat linear atau tidaknya dilihat dari signifikansinya harus lebih besar dari 0.05 dan nilai Fhitung harus lebih kecil dari $F_{\text {tabel. }}$

Tahap selanjutnya yaitu analisis data meliputi persamaan regresi dan koefisien determinasi. Persamaan regresi digunakan untuk meramalkan apakah variabel $\mathrm{X}$ memiliki persamaan dengan variabel $Y$ ditulis dengan rumus $\mathrm{Y}=\mathrm{a}+\mathrm{bX}$. Sedangkan koefisien determinasi digunakan untuk mengetahui seberapa besar hubungan variabel $\mathrm{X}$ dengan variabel $\mathrm{Y}$. Koefisien determinasi ditulis $\mathrm{r}^{2} \mathrm{yx} 1$. Bentuk persamaan regresi dalam penelitian ini diperoleh data $Y$ $=71.985+0.022$. Serta koefisien determinasi diperoleh data $0.123^{2}=0.015$ atau $1.5 \%$ variabel X menentukan hasil variabel Y.

Selanjutnya tahap terakhir yaitu uji signifikansi melalui uji $t$ yang bertujuan untuk mengetahui ada atau tidaknya pengaruh antara metode guide reading $(\mathrm{X})$ terhadap motivasi belajar siswa (Y). Berdasarkan hasil uji signifikansi melalui uji t diperoleh nilai thitung $=0.665$ lebih kecil dari $t_{\text {tabel }}=0.725$ yang dilihat pada tabel distribusi t dengan $\mathrm{dk}$ 31, dan hasil nilai signifikansi 0.511 lebih besar dari 0.05. Maka $\mathrm{H}_{\mathrm{o}}$ terima dan $\mathrm{H}_{\mathrm{a}}$ tolak yang artinya metode Guide reading tidak memiliki pengaruh yang signifikan terhadap motivasi belajar siswa. Karena syarat dari uji t yaitu thitung harus lebih besar dari tabel dengan nilai signifikansi kurang dari 0.05.

Penelitian ini hasilnya dapat menunjukkan bahwa metode Guide reading tidak memiliki pengaruh terhadap motivasi belajar siswa dalam teori membaca nyaring. Hal ini dibuktikan dengan hasil uji thitung< tabel yaitu $0.665<0.725$ yang menyatakan 
bahwa $\mathrm{H}_{\mathrm{o}}$ terima dan $\mathrm{H}_{\mathrm{a}}$ tolak. Jadi dapat disimpulkan bahwa metode Guide reading tidak memiliki pengaruh terhadap motivasi belajar siswa.

\section{KESIMPULAN DAN IMPLIKASI}

\section{Kesimpulan}

Berdasarkan hasil analisis data penelitian mengenai signifikansi metode guide reading terhadap motivasi belajar dalam teori membaca nyaring yang dilaksanakan di SDN 4 Cisande Kabupaten Sukabumi dengan analisis regresi, dapat disimpulkan bahwa tidak terdapat pengaruh yang signifikan penggunaan metode Guide reading terhadap motivasi belajar siswa dalam teori membaca nyaring di kelas I SDN 4 Cisande Kabupaten Sukabumi. Hal ini sesuai dengan kriteria pengujian yaitu terima $\mathrm{H}_{\mathrm{o}}$ yang berarti tidak terdapat korelasi positif yang terlihat dari hasil pengujian hipotesis statistika pada hasil uji t. Hal ini dapat dibuktikan dengan persamaan regresi diperoleh data $\mathrm{Y}=71.985$ + 0.022. Serta koefisien determinasi diperoleh data $0.123^{2}=0.015$ atau $1.5 \%$ variabel $\mathrm{X}$ menentukan hasil variabel $\mathrm{Y}$ danhasil uji signifikansi melalui uji $t$ diperoleh nilai thitungsebesar 0.665 lebih kecil dari ttabel yaitu 0.725 dengan nilai signifikansi 0.511 lebih besar dari 0.05 maka terima $\mathrm{H}_{\mathrm{o}}$ dan tolak $\mathrm{H}_{\mathrm{a}}$.

\section{Implikasi}

Guru hendaknya mampu memilih metode yang ada dalam proses pembelajaran mestilah sesuai dengan materi apa yang direncanakan serta yang akan diajarkan, metode yang mampu memberikan motivasi belajar kepada siswa. Guru harus mampu memberi motivasi yang tinggi kepada peserta didik pada proses terjadinya kegiatan membaca, dan guru bisa membangun suasana pembelajaran dikelas yang kondusif serta menyenangkan, maka diharapkan apa yang menjadi tujuan dari proses pembelajaran sesuai dengan perencanaan dapat terimplementasikan serta dicapai dengan baik.

Sekolah harus lebih memperhatikan fasilitas sarana dan prasarana sekolah yang memadai, sehingga siswa mudah mendapatkan bahan bacaan. Semua siswa diharapkan memiliki keaktifan serta selalu ikut serta pada proses pembelajaran dalam upaya pencapaian tujuan pembelajaran.

Kepala sekolah sudah sepantasnyalah mempunyai kemampuan untuk mendorong guru dalam mengembangkan metode dalam kegiatan pembelajaran yang berorientasi terhadap keaktifan siswa, dan juga kepala sekolah hendaknya dapat memfasilitasi guru agar mampu menggunakan bermacammacam inovasi dalam penggunaan metode pembelajaran di sekolahnya. Sehingga tujuan pembelajaran diharapkan tercapai dengan baik dan tentunya motivasi siswa semakin tinggi dalam belajar.

\section{DAFTAR PUSTAKA}

Asra dan Sumiati. 2011. Metode pembelajaran. Wacana Prima, Bandung.

Dalman. 2014. Keterangan membaca. Raja grafindo, Jakarta.

Emzir. 2011. Metodologi penelitian pendidikan kuantitatif dan kualitatif. Raja Grafindo, Jakarta.

Fathurrohman P. 2007. Strategi belajar mengajar melalui penanaman konsep umum dan konsep islami. Refika Aditama, Bandung.

Kartajaya H. 2010. Brand operation the official MIM academy course book. Esensi Erlangga Group, Jakarta.

Rahim F. 2009. Pengajaran membaca di sekolah dasar. Bumi Aksara, Jakarta. 
Sardiman. 2011. Interaksi dan motivasi belajar mengajar. Raja Grafindo Persada, Jakarta.

Sumantri dkk. 2015. Strategi pembelajaran teori dan praktik di tingkat pendidikan dasar. Raja Grafindo Persada, Jakarta.
Tarigan HG. 2015. Membaca ekspresif. Angkasa, Bandung.

Yunus A. 2012. Pembelajaran membaca berbasis pendidikan karakter. Refika Aditama, Bandung. 